\title{
Getting Teenagers to Participate: A Survey of the Youth Council of the City of Lausanne
}

\author{
Olivier Glassey and Camille-Angelo Aglione \\ Swiss Graduate School of Public Administration (IDHEAP), Quartier Mouline UNIL, 1015 \\ Lausanne, Switzerland \\ olivier.glassey@idheap.unil.ch, camille-angelo.aglione@unil.ch
}

\begin{abstract}
This paper discusses the results of a survey on a concrete case of eParticipation, i.e. a campaign to get teenagers to participate in the Youth Council of the City of Lausanne. We analyse both the traditional tools (billboard ads, newspapers, official communication through schools) and the online tools (Web page, Facebook, YouTube). During our survey we used mixed methods: an online questionnaire (1360 respondents), documentary analysis of the Youth Council candidates' application files, and interviews. We then analysed the impacts of the campaign in terms of participation under different angles, amongst other diffusion channels and use of humour.
\end{abstract}

Keywords: eParticipation, social media, youth council, persona, campaigning, survey, channels.

\section{Introduction}

eParticipation is a research domain that is growing but where concrete surveys are not so numerous. This paper is reporting on one such survey, where we analysed a campaign that aimed at raising applications for the Youth Council of the City of Lausanne. This campaign used traditional communication channels (billboard ads, newspapers), as well as Internet, Facebook and YouTube. Indeed the person in charge of the Youth department of the City of Lausanne staged an online campaign playing with clichés on civil servants and tried to raise a buzz around the Youth Council.

We used an online questionnaire that was sent through a job market website for teenagers and students. We received a surprising high number of answers (1360). Furthermore we were able to analyse the applications files of all candidates and we conducted a set of interviews with five candidates that were elected to the Youth council. We studied the impacts of the campaign under different angles, such as diffusion channels, or use of humour.

\subsection{Youth Council of the City of Lausanne}

In 2004 a member of the Parliament of the City of Lausanne asked for the creation of Youth Council for the City of Lausanne, as well as for the surrounding municipalities. 
In 2009 the city government presented a report that defined the legal framework for such a project. It was based of the Swiss Federal Constitution that recognises the rights of the youth to participate and to express their ideas and their needs, and on the Constitution of the Canton of Vaud that states that the Canton and the municipalities should prepare kids and teenagers for their future citizen rights, by supporting various forms of participative experiences.

The Youth Council comprises 60 members between 13 and 25 years old, living, working or studying in Lausanne

- 4 seats for University students;

- 12 seats for professional schools;

- 13 seats for high schools;

- 13 seats for secondary schools;

- 18 seats for various representatives of the city's life and associations.

The Youth Council has an annual budget of CHF 100'000.-, amongst which 30'000 to support projects launched by young people, 50'000 to celebrate those who become of voting age (a book is sent to all residents turning 18) and 20'000 for the operating budget. The members of the Youth Council do not have any reimbursement.

\subsection{Recruiting Campaign}

The City's delegate of youth affairs wanted to create a persona to be able to relate more directly with young people. "We did not want a super-hero, it was quite the opposite. We wanted a persona that would look like a classical civil servant. (...) We wanted to talk to the youths, but they are not uniform. We were looking for something funny and off the beaten path, in order to show that the City was not too serious and that the Council was not a thing for old people." The delegate, assisted by a communication agency, created a persona called "Jean-Michel Utile" (aka JohnMichael Useful). The persona has thick glasses, a very old fashioned suit and a wornout briefcase. At first they wanted to recruit a model, but eventually it was the delegate himself that played the role, due to lack of time to find one.

Posters were created (Fig. 1) and they were placated both on standard advertising billboards and on dedicated locations for political campaigns. These locations are usually reserved for candidates and parties, but the City of Lausanne authorized their use for the recruiting campaign.

The delegate and the communication agency soon realized that it would probably not be enough to get the youths interested. On July $27^{\text {th }} 2010$ they launched an online campaign, by using Facebook and YouTube videos. During one month, they posted one video a day on YouTube. These clips showed John-Michael Useful in various surroundings (a football field, a skate park, a diving board at the swimming pool, etc.) and each time Mr Useful would be hopelessly ridiculous. Each clip would end with our hero saying "Make yourself useful too, come and join John-Michael Useful" with a link to a dedicated website. No video ever mentioned the Youth Council or the City of Lausanne, until the last clip where John-Michael Useful explained the concept and asked the youth to send their application for the Youth Council. The deadline was set to September $30^{\text {th }}, 2010$. 


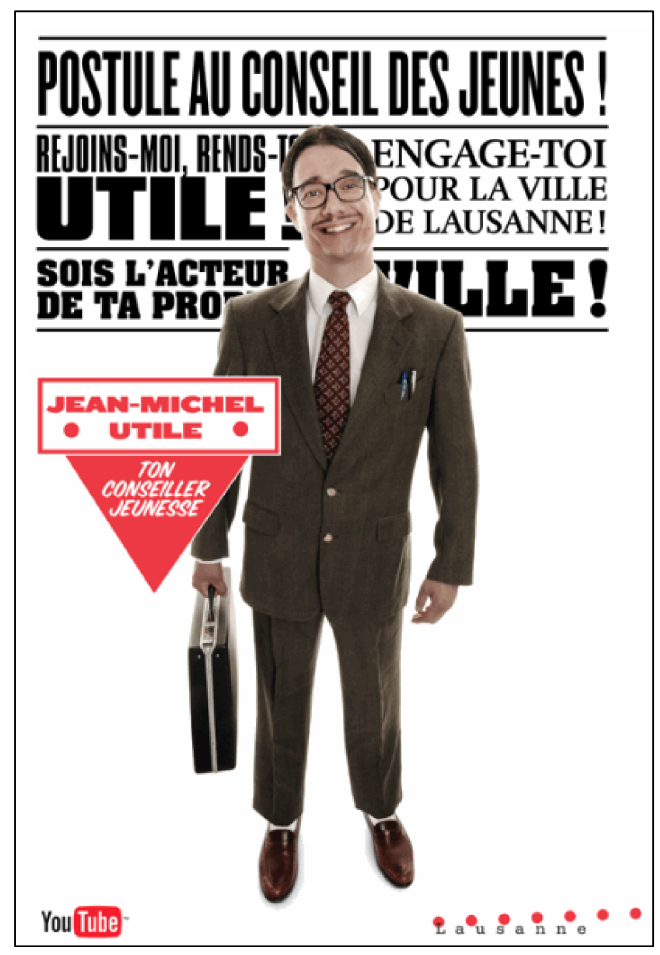

Fig. 1. The John-Michael Useful billboard ad, asking the youth to apply for the Youth Council

A Facebook profile was also created for John-Michael Useful, where he would post regularly and gather about 500 friends during the campaign. What is worth mentioning is that City of Lausanne blocks the use of Facebook by its employees, and that they had to ask for an exception to the Municipal Council (i.e. the executive branch of the local government). A dedicated machine with a separate Internet access had to be set up. This is not only an anecdote, but it shows how far certain public administrations can be from using social media for their official communication and for opening a dialogue with the people.

Those who were interested in becoming members of the Youth Council had to turn in an application file. They were not elected by the young people of Lausanne, but selected by a committee headed by the City's delegate of youth affairs.

\section{3 eParticipation}

Governments seek to encourage participation in order to improve the efficiency, acceptance, and legitimacy of political processes [1]. Various information and communication technologies (ICTs) are available for eParticipation: discussion forums, electronic voting systems, group decision support systems, and web logging (blogs). [2] describes eDemocracy as the use of information and communication technologies to engage citizens, to support the democratic decision-making processes and to strengthen representative democracy. [3] defines eParticipation as the use of 
ICTs to support information provision and "top-down" engagement, i.e. governmentled initiatives, or "ground-up" efforts to empower citizens, civil society organizations and other democratically constituted groups to gain the support of their elected representatives. There are many examples of surveys on eDemocracy, such as [4] who take the case of Switzerland where citizens are often called to the polls either to vote for parties and candidates or, even more often, to decide on direct-democratic votes at the three different political levels. Even if eParticipation is a relatively new research field, projects and tools are increasing thanks to governmental support [5], such as Demo-Net.org. Finally the young people are a target of eParticipation that are specifically studied by authors such as $[6,7,8]$.

This paper does not aim at contributing theoretically to the analysis of eParticipation. Its goal is rather to take a concrete case of use of ICTs in the domain of youth participation and to explore a few topics pertaining to the domain of participation.

\section{Survey}

Three sources of survey were mobilized (see Table 1) in order to assess (i) the impacts of the recruiting campaign (did the young people see it?); (ii) the effectiveness of the campaign (i.e. did it engage young people to be candidate?).

We set up an online questionnaire using SurveyMonkey and we sent a link via email to all members of an online job market website developed especially for people under 22. The questionnaire comprised five parts:

- Independent variables: age, gender, place of residence, activity, etc.

- Dependant variables (closed questions):

o Visibility of the campaign;

o Impacts of the campaign;

o Contents of the campaign;

- $\quad$ Conclusions and general remarks (open questions).

Table 1. Survey sources

\begin{tabular}{|c|c|}
\hline Source & Description \\
\hline Online questionnaire & $\begin{array}{l}26 \text { '000 questionnaires sent via email; 1'361 valid } \\
\text { responses. }\end{array}$ \\
\hline Document analysis & $\begin{array}{l}\text { Analysis of motivations for becoming a member of } \\
\text { the Youth Council; } 82 \text { application files, amongst } \\
\text { them } 62 \text { useable. }\end{array}$ \\
\hline Semi-direct interviews & $\begin{array}{l}\text { Interviews with } 5 \text { elected members of the Youth } \\
\text { Council. }\end{array}$ \\
\hline
\end{tabular}

We were able to have access to the application files of the candidates. As most of them contained a motivation letter, we were able to analyse these. Furthermore three additional questions where sent via email to the members of the Youth Council (amongst them how did you first hear about the youth council?) and 29 of them 
answered. Finally 5 members of the Youth Council were interviewed, mostly on their motivations to participate.

The questionnaire used the conditional branching features of SurveyMonkey to skip questions, e.g. if respondents had not seen the video clips then no questions were asked about them. If respondents remembered having seen or heard about JohnMichal Useful, they would be asked questions such as: did you visit the website? Did you forward links on the campaign? Did you get the message? Did you find it funny? They were of course also asked if they had applied to be candidate for the Youth Council.

\section{Main Results}

Fist let us mention that most respondents were over 18 (76.4\%) and this is certainly due to the communication channel used to send the questionnaire, i.e. a job market website that would probably attract more people over 18 than under that age. A more intriguing result was the over-representation of girls (69\%), whereas a study made by [9] indicated that boys do have more interest for political topics than girls. We do not however have any clear indication on why such a difference appeared. Last, there were more students in the sample than in the general population of the City of Lausanne and its surrounding municipalities. We took the bias into account for the exploitation of our results.

Regarding the visibility of the campaign, let us mention that $29 \%$ of the online questionnaire respondents did remember the John-Michael Useful campaign. However most of them did hear about it through traditional channels. Moreover the impacts of the YouTube videos were very limited (Fig. 2). It seems that the online campaign did not create the buzz it had hoped for.

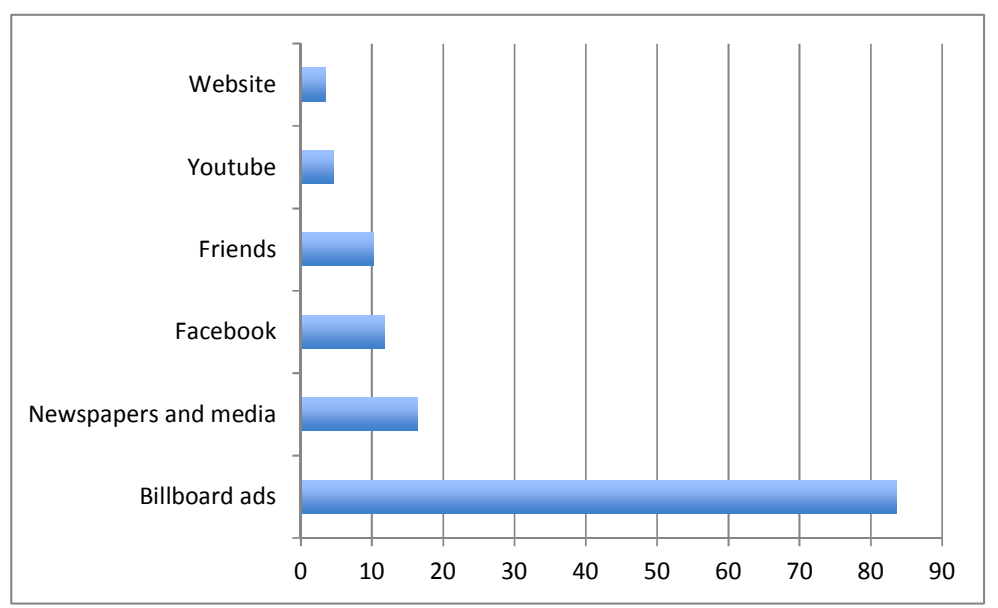

Fig. 2. How did you hear about John-Michael Useful (in \%, several answers possible)? 
Billboard ads are most frequently mentioned amongst all age categories, but people aged 18-25 did mention them more than the 13-17 age category (+ 8.6 points). Newspaper and media were listed equally by the 13-17 and 18-25 age category. Gender did not have any notable influence on these results. On the other hand, Facebook was mentioned more frequently amongst the 13-17 age category than the $18-25$ (+ 10 points). Furthermore younger people seem to have forwarded links or discussed the campaign more: $32 \%$ of the 13-17 respondents against $24 \%$ for the 18 25 age category. This is consistent with the work of [10] on eParticipation in Cataluña, who showed that the younger the participants are, the more they enjoy online participation.

Here we cannot conclude from a quick look of Fig. 2 that generally billboard ads and traditional media are more efficient in reaching their audience than social media. Indeed there is certainly also the fact that public administrations (along with their communication agencies) usually master the traditional communication channels rather well, whereas they seem to have more difficulties with social media. The difference of impact between traditional channels and social media could also be linked to the quality of the campaign. Of course we cannot prove this but some indications are given by the answers given by the respondents on the effectiveness of the campaign. Indeed a majority of them did not find the campaign effective $(69 \%$ of them found the campaign to be rather or very ineffective), although a short majority of them found it clear (Fig. 3). Regarding the use of humour, a very small majority of respondents found it funny, but with more positive feedback for the 13-17 age category $(54 \%)$ than the $18-25(48 \%)$. Let us also mention for some the humour probably got lost, as about $10 \%$ of the respondents answered that "John-Michael Useful" does really exist.

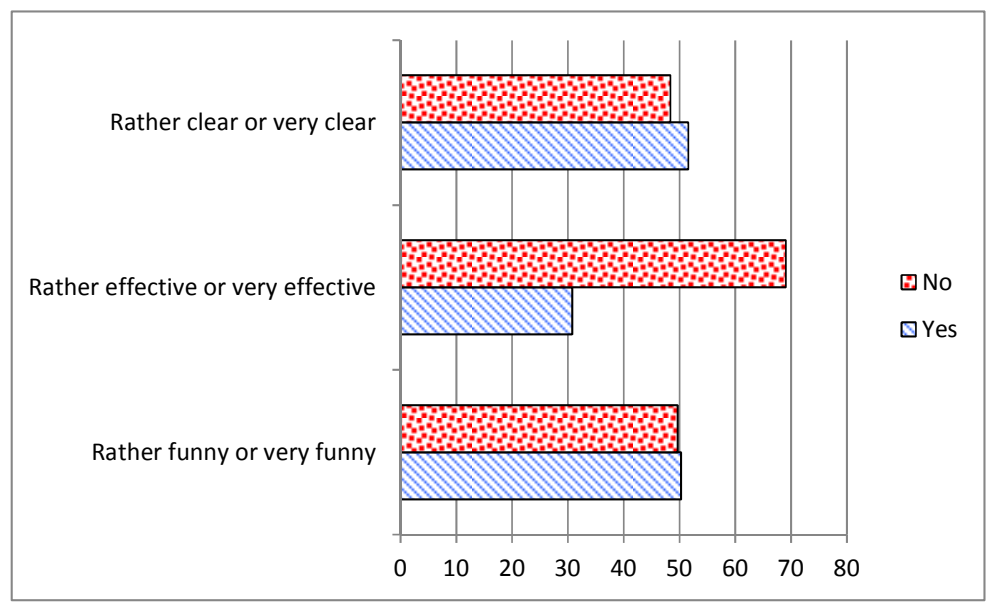

Fig. 3. What did you think about the campaign (in \%, aggregated answers)?

The analysis of the application files was of course not focused on the campaign, but rather on the motivations for the youths to participate. We will not go into the details, but there were three mains topics that came out: 
- Local: half of the candidates mentioned their ties with the City of Lausanne in their motivation letter and said they wanted to participate and exchange with others in order to make it a better place for the youth.

- Family: several candidates indicated that they hear about politics at home, that they discuss politics with their parents, or that members of their family are politically active and that they want to follow their path. This finding goes along the lines of the statement of [11] who wrote in 1996 that politics was one of the tops values transmitted by parents to their kids.

- Engagement: about one third of the candidates have previous experience in participation, either in their schools, in associations, or even in youth sections of local political parties. They see the Youth Council as a place to discuss topics of interests for them, to learn, and to "try out things without having too much pressure to decide or to impose things".

During the interviews, motivations of candidates were also touched upon, but other topics such as the use of online campaigning and the use of humour were discussed. The use of Facebook during the campaign did not seem to fully convince the interviewed candidates. One of them said that, although he was "friend" with JohnMichael Useful, he would still use the phone to contact him. Moreover, none of them have posted on his wall. Regarding the video clips, the interviewees seem to consider them as failures. One of them, who saw the videos only after having applied for the Youth Council, even told us that he thought "what am I doing here? This is not the image I want to give for the City of Lausanne". The expected buzz was not met, and the use of humour does not seem to have been successful in engaging the youth. This would go along the conclusions of [12] who write that in most cases humour is useful to raise attention, but that teachers or politics should look serious and use sound argumentations.

\section{Conclusion}

The analysis John-Michael Useful campaign shows that the use of ICTs and more specifically of online tools such as social networks do not automatically enhance participation. This is consistent with previous work of [13] in Switzerland, where the main results showed that traditional channels for participation were still mainly used, rather than eParticipation tools.

Furthermore our survey indicates that the reasons to participate are also rather traditional (local engagement, family, previous participatory experiences), and that trying to create the buzz with a type of viral marketing campaign did not seem to be successful in raising participation. On the other hand, the strength of the campaign was that it did have good impacts in terms of visibility. It did reach different age and activity categories and it was able to raise awareness about the Youth Council. However the traditional channels (ads and newspapers) were again the ones that were most frequently remembered by the respondents.

Let the delegate of youth affairs of the City of Lausanne have the final words (on the use of social media for which he was directly responsible): "We thought that it 
would come along naturally, which was not the case. We should have had more follow-up, by people who master both the technical aspects and the etiquette of this platform". In addition to this comment, the communication agency estimates the time required to properly maintain such a Facebook profile at about one to two hours a day. This would certainly lead us to think that setting up a Facebook account or publishing videos on YouTube is far from being sufficient to enhance eParticipation, and that resources must be planned in order to sustain the dialogue with the participants.

Acknowledgments. The authors wish to thank the City of Lausanne and its delegate of Youth affairs for letting us conduct this case study.

\section{References}

1. Sanford, C.S., Rose, J.: Characterizing eParticipation. International Journal of Information Management 27, 406-421 (2007)

2. Macintosh, A.: Characterizing e-Participation in Policy-Making. In: Proceedings of the 37th Annual Hawaii International Conference on System Sciences, HICSS-37 (2004)

3. Macintosh, A., Whyte, A.: Evaluating how eParticipation changes local democracy. In: Irani, Z., Ghoneim, A. (eds.) Proceedings of the eGovernment Workshop. Brunel University, London (2006)

4. Ladner, A., Felder, G., Schädel, L.: From e-voting to smart-voting - e-Tools in and for elections and direct democracy in Switzerland. IDHEAP Working Paper 4/2008 (2008)

5. Tambouris, E., Liotas, N., Tarabanis, K.: A Framework for Assessing eParticipation Projects and Tools. In: Proceedings of the 40th Annual Hawaii International Conference on System Sciences, HICSS-40 (2007)

6. Coleman, S.: Digital Voices and Analogue Citizenship: Bridging the Gap between Young People and the Democratic Process. Public Policy Research 13(4), 257-261 (2006)

7. Banaji, S., Buckingham, D.: Young People, the Internet, and Civic Participation: An overview of key Findings from the Civicweb Project. International Journal of Learning and Media 2(1), 15-24 (2010)

8. Taylor-Smith, E., Kimpeler, S., Pruulmahnd-Vengerfeldt, P.: Distributed Discussion: an Integrated eParticipation Model for Engaging young People in Technology Policy. In: Charalabidis, Y., Koussouris, S. (eds.) Empowering Open and Collaborative Governance. Springer, Germany (2012)

9. Oser, F., Biedermann, H.: Jeunesse sans politique? Résultats de l'étude IEA 2003 relative aux connaissances politiques, à la compréhension de la démocratie et à l'engagement social chez les jeunes en Suisse et en comparaison avec 27 autres pays. Editions Loisirs et Pédagogie (2004)

10. Colombo, C.: e-Participation Experiences and Local Government in Catalonia: An Explanatory Analysis. In: Tambouris, E., Macintosh, A., Glassey, O. (eds.) ePart 2010. LNCS, vol. 6229, pp. 82-94. Springer, Heidelberg (2010)

11. Muxel, A.: Les jeunes et la politique. Hachette Livre, Paris (1996)

12. Graby, F.: Humour et comique en publicité. Editions EMS, Paris (2001)

13. Glassey, O.: A Survey on Participation at Geneva"s Constituent Assembly. In: Tambouris, E., Macintosh, A., Glassey, O. (eds.) ePart 2010. LNCS, vol. 6229, pp. 151-161. Springer, Heidelberg (2010) 